\title{
The Design Of Antimicrobial LL37-Modified Collagen-Hyaluronic Acid Detachable Multilayers
}

\author{
Margaret E. Cassin ${ }^{1}$, Andrew J. Ford ${ }^{1}$, Sophia M. Orbach ${ }^{1}$, Scott E. Saverot ${ }^{2}$, and \\ Padmavathy Rajagopalan ${ }^{1,3, *}$
}

1. Department of Chemical Engineering, Virginia Tech, Blacksburg VA 24061.

2. School of Biomedical Engineering and Sciences, Virginia Tech, Blacksburg VA 24061.

3. ICTAS Center for Systems Biology of Engineered Tissues, Virginia Tech, Blacksburg VA 24061.

${ }^{*}$ Corresponding Author

*Corresponding Author Information:

Prof. Padmavathy Rajagopalan

Department of Chemical Engineering

ICTAS Center for Systems Biology of Engineered Tissues

Virginia Tech, Blacksburg VA 24061

Email: padmar@vt.edu, Tel: $\underline{540-231-4851}$, 


\section{Author Information}

Ms. Margaret E. Cassin

Department of Chemical Engineering

Virginia Tech, Blacksburg VA 24061

Email: mec333@vt.edu, Tel: 540-231-4851

\section{Mr. Andrew J. Ford}

Department of Chemical Engineering

Virginia Tech, Blacksburg VA 24061

Email: ford89@vt.edu, Tel: 540-231-4851

\section{Ms. Sophia M. Orbach}

Department of Chemical Engineering

Virginia Tech, Blacksburg VA 24061

Email: smorbach@vt.edu, Tel: 540-231-4851

\section{Mr. Scott E. Saverot}

School of Biomedical Engineering and Sciences

Virginia Tech, Blacksburg VA 24061

Email: ssaverot@vt.edu, Tel: 540-231-4851

\section{${ }^{*}$ Corresponding Author Information:}

\section{Prof. Padmavathy Rajagopalan}

Department of Chemical Engineering

ICTAS Center for Systems Biology of Engineered Tissues

Virginia Tech, Blacksburg VA 24061

Email: padmar@vt.edu, Tel: 540-231-4851, 


\section{ABSTRACT}

The design of antimicrobial membranes and thin films are critical for the design of biomaterials that can combat bacterial contamination. Since the long-term use of conventional antibiotics can result in bacterial resistance, there is a critical need to incorporate natural antimicrobial peptides (AMPs) that not only prevent a wide range of pathogens from causing infections but can also promote many beneficial outcomes in wounded tissues. We report the design and antimicrobial properties of detachable collagen (COL)/hyaluronic acid (HA) polyelectrolyte multilayers (PEMs) modified with LL37, a naturally occurring human AMP. LL-37 was physically adsorbed and chemically immobilized on the surface of PEMs. The antimicrobial and cytotoxic properties of PEMs were tested with Gram-negative Escherichia coli (E. coli, strain DH10B) and primary rat hepatocytes, respectively. The ability to prevent bacterial adhesion and to neutralize an E. coli layer was investigated as a function of LL-37 concentration. An interesting trend was that even unmodified PEMs exhibited a $40 \%$ reduction in bacterial adhesion. When LL-37 was physically adsorbed on PEMs, bacterial adhesion was significantly lower on the surface of the films as well as in the surrounding broth. Immobilizing LL-37 resulted in less than $3 \%$ bacterial adhesion on the surface due to the presence of the peptide. LL-37 modified PEMs did not result in any cytotoxicity up to input concentrations of $16 \mu \mathrm{M}$. More importantly, urea and albumin secretion by hepatocytes were unaffected even at high LL-37 concentrations. The COL/HA PEMs can serve as antimicrobial coatings, biological membranes and as in vitro platforms to investigate pathogen-tissue interactions.

KEYWORDS: Polyelectrolyte multilayers, LL-37, antimicrobial, collagen, hyaluronic acid 


\section{INTRODUCTION}

Infections caused by antibiotic-resistant pathogens can result in serious health risks and high healthcare costs [1-5]. Since the misuse of conventional antibiotics has been shown to result in the emergence of drug-resistant pathogens, antimicrobial peptides (AMPs) are emerging as an alternative. In the field of biomaterials, it is critical to prevent bacterial adhesion and biofilm formation in order to prevent contamination of biomedical devices. For example, contact lenses, catheters, and implants are frequently contaminated by bacteria. Strategies that can prevent harmful bacteria from adhering to such materials will be very useful in mitigating long-term health complications.

AMPs are an inherent component of the body's defense against a wide range of pathogens [6-9]. They are short peptide sequences (<100 amino acids) that can exhibit broad-spectrum function against Gram-positive and Gram-negative bacteria, fungi, and certain enveloped viruses [10]. Hundreds of AMPs have been identified and are present at constitutive levels in organisms $[8,11]$. AMPs typically exhibit a positive charge (up to +9) and have an amphipathic structure [10]. The separation of the charged groups from hydrophobic residues on the peptide promotes its interaction with the negatively charged bacterial membrane and subsequent penetration into the hydrophobic lipid bilayer [12]. AMPs can disrupt microbial membranes through various mechanisms such as pore formation (barrel-stave or toroidal-pore model) or detergent-like solubilization (carpet or detergent model) [13] (Figure 1A-C). The increase in permeability can cause outflow of cellular contents into the extracellular space, ultimately killing the microbe.

LL-37 (LLGDFFRKSKEKIGKEFKRIVQRIKDFLRNLVPRTES; L=Leucine, G=Glycine, D= Aspartic Acid, $\mathrm{F}=$ Phenylalanine, $\mathrm{R}=$ Arginine, $\mathrm{K}=$ Lysine, $\mathrm{S}=$ Serine, $\mathrm{E}=$ Glutamic acid, 
$\mathrm{I}=$ Isoleucine, $\mathrm{V}=$ Valine, $\mathrm{Q}=$ Glutamine, $\mathrm{N}=$ Asparagine, $\mathrm{P}=$ Proline, $\mathrm{T}=$ Threonine) is a human cathelicidin AMP that contains 37 amino acids and has a molecular weight of 4.5 $\mathrm{kDa}[14,15]$. This peptide is secreted by granulocytes and is found in blood plasma at constitutive concentrations ranging from 1-2 $\mu \mathrm{g} \mathrm{mL}^{-1}(0.2-0.4 \mu \mathrm{M})$ and up to $25 \mu \mathrm{M}$ in the presence of infectious pathogens [16]. The cationic and amphipathic nature of LL-37 promotes interaction with bacteria cell membranes though the toroidal pore mechanism [17].

Although natural AMPs are very effective, their cost relative to synthetic peptides has resulted in many studies conducted using synthetic AMPs [18-20]. Although, synthetic peptides can interact with bacterial membranes and cause microbial death, they do not enable interactions with the host tissue. For example, natural AMPs can exhibit beneficial properties during wound healing such as recruiting neutrophils to a site of injury. However, significantly higher concentrations of synthetic AMPs are required to deliver the same antimicrobial properties as their natural counterparts. Therefore, incorporating natural AMP sequences, such as LL-37, has the potential to kill bacteria in addition to aiding in the immune response at physiologically relevant concentrations.

When bacteria and other pathogens infect a tissue, they interact with the extracellular matrix $(\mathrm{ECM})$ components found in connective tissue. For this reason, studies have been conducted to better understand how proteins and other ECM components either promote or prevent pathogen adhesion and proliferation [21]. There is emerging evidence that certain ECM components, specifically proteoglycans such as hyaluronic acid (HA), exhibit antimicrobial properties, attributed in part to their hydrated structures [22]. 
Our goal was to investigate whether two commonly found ECM components such as type 1 collagen (COL) and HA in combination with the human AMP, LL-37 would be effective in preventing bacterial adhesion on surfaces and in solution. We designed COL/HA polyelectrolyte multilayers (PEMs) to control the physical properties as well as the surface chemistry. PEMs are typically assembled on charged substrates through the layer-by-layer (LbL) deposition of alternatively charged polyelectrolytes (PEs) [23]. A significant advance of our approach is the ability to assemble ECM-based thin films on a hydrophobic substrate that enables easy detachment without the need for a sacrificial layer or additional steps [24, 25]. We report the design and function of LL-37-modified COL/HA PEMs. In this study, the AMP was either physically adsorbed (physisorbed) or immobilized. The antimicrobial properties were studied as a function of preventing microbial adhesion and in the ability to neutralize an E. coli layer. LL-37 modified PEMs were effective in preventing bacterial adhesion on substrates as well as in the surrounding broth. Studies were also conducted with mammalian rat hepatocytes to determine the potential cytotoxicity. Multilayers composed of ECM components provide a platform to systematically investigate the interaction of pathogens and connective tissues. Furthermore, such films can also be used to design antimicrobial coatings and engineered tissues.

\section{MATERIALS and METHODS}

Glacial acetic acid and a Pierce ${ }^{\circledR}$ FITC antibody labeling kit were obtained from ThermoFisher Scientific. LL-37 was obtained from AnaSpec, Inc. (Fremont CA). Phosphatebuffered saline (PBS), Dulbecco's modified Eagle medium (DMEM), penicillinstreptomycin and a LIVE/DEAD® BacLight ${ }^{\mathrm{TM}}$ bacterial viability kit were obtained from Invitrogen Life Technologies. E. coli strain $\mathrm{DH} 10 \mathrm{~B}$ was a gift from the Dr. B. 
Mukhopadhyay at Virginia Tech. Glucagon, calcium chloride, hydrocortisone, sodium dodecyl sulfate (SDS), glutaraldehyde, calf thymus DNA, Hoechst 33258 pentahydratebis-benzimide dye, Mueller-Hinton broth powder and collagenase type IV were obtained from Sigma-Aldrich (St. Louis, MO). All other chemicals were obtained from Fisher Scientific (Pittsburgh, PA) unless otherwise stated.

Extraction of COL: COL was extracted by dissecting tendons from rat tails [26] that were dissolved in $3 \% \mathrm{v} / \mathrm{v}$ acetic acid $\left(\mathrm{CH}_{3} \mathrm{COOH}\right)$ and centrifuged at $13,000 \times \mathrm{g}$. A $30 \%$ $\mathrm{w} / \mathrm{v}$ sodium chloride $(\mathrm{NaCl})$ solution was added to the supernatant and centrifuged. The pellet was diluted in $0.6 \% \mathrm{v} / \mathrm{v} \mathrm{CH}_{3} \mathrm{COOH}$ for $48 \mathrm{~h}$ and dialyzed in $1 \mathrm{mN} \mathrm{HCl}$. The final COL solution (2.5-3.0 $\left.\mathrm{mg} \mathrm{mL}^{-1}\right)$ was maintained at a $\mathrm{pH}$ of 3.1 .

Assembly of PEMs: Detachable PEMs were assembled using COL and HA. COL (cationic) was dissolved in $1 \% \mathrm{CH}_{3} \mathrm{COOH}$ at a concentration of $1.5 \mathrm{mg} \mathrm{mL}^{-1}$. $\mathrm{HA}$ (anionic) was dissolved in $18 \mathrm{M} \Omega \cdot \mathrm{cm}$ DI water at a concentration of $1.5 \mathrm{mg} \mathrm{mL}^{-1}$. The $\mathrm{pH}$ of the PEs and rinse solutions was maintained at 4.0. PEMs were assembled on poly(tetrafluoroethylene) (PTFE; McMaster-Carr, Elmhust, IL) substrates using a robotic deposition system (StratoSequence VI, NanoStrata Inc., Tallahassee, FL) [25]. The PTFE substrates were cleaned prior to deposition by sonication in toluene for $1 \mathrm{~h}$. The water contact angle values were greater than $110^{\circ}$ for clean PTFE substrates. PEMs were assembled by first depositing a HA layer followed by COL. Deposition times for each PE layer were maintained at $30 \mathrm{~min}$. The PEMs were rinsed for $10 \mathrm{~min}$ between PE depositions with DI water. 15 bilayer (BL) PEMs were cross-linked with $8 \%$ w/v glutaraldehyde for $30 \mathrm{~s}$, rinsed and air-dried. HA/COL PEMs were detached from the underlying hydrophobic PTFE substrate. 
Mass Retention under Aqueous Conditions: Dry, detached COL/HA PEMs were weighed and placed in PBS $\left(1 \mathrm{X} ; 37^{\circ} \mathrm{C}\right)$ for 3,7 , or 14 days. After the designated time period, the PEMs were dried under vacuum for $24 \mathrm{~h}$ at $50^{\circ} \mathrm{C}$. The mass of the PEM was recorded. Mass retention was calculated to determine the degree of degradation of the PEM in an aqueous environment.

Profilometry: A DektakXT profiler (Bruker, Billerica MA) was used to determine the thickness of dry and hydrated detachable PEMs. A scan length of $1000 \mu \mathrm{m}$ was taken over $20 \mathrm{~s}$ for each sample. Thickness values were measured at five different locations per sample. Hydrated thicknesses were obtained by submerging the PEMs in DI water for $20 \mathrm{~min}$ and subsequently wicking off excess liquid.

Elastic Modulus and Surface Topography of PEMs: The Young's moduli (YM) of dry and hydrated PEMs were obtained using a Veeco MultiMode Atomic Force Microscope (AFM; Veeco, Santa Barbara CA) in a liquid cell chamber. Pyramidal SiN cantilever tips $\left(\mathrm{k}=0.06 \mathrm{~N} \mathrm{~m}^{-1}\right.$; Bruker AFM Probes, Camarillo $\mathrm{CA}$ ) were used for all measurements in contact mode [26]. Force-distance curves were obtained using a Z-scan distance of 1 $\mu \mathrm{m}$ and $1 \mathrm{~Hz}$. The YM was obtained by fitting the force-distance curves to a modified Hertz-cone model (Equations 1 and 2).

Equation $1 \quad F=k\left(d-d_{o}\right)$

Equation $2 \quad F=\frac{2 \tan \alpha}{\pi}\left[\frac{E}{1-v^{2}}\right] \delta^{2}$

$F=$ applied force, $\alpha=$ half open tip angle $\left(18^{\circ}\right), E=Y M, k=$ spring constant of the cantilever, $v=$ Poisson's ratio (constant $=0.40) d=$ deflection of the cantilever, $d_{o}=$ deflection point during contact, and $\delta=$ indentation. Indentations up to $10 \%$ of the overall 
PEM thickness were used when obtaining force-distance curves. Surface images of PEMs were imaged on the same instrument in contact mode.

Optical Transmission: The optical transmission of light through PEMs between 400 and $900 \mathrm{~nm}$ was measured on a SpectraMax M2 UV/vis spectrophotometer (Molecular Devices, Sunnyvale CA). Measurements were conducted on dry and hydrated multilayers. Hydrated PEMs were maintained in DI water for 20 min prior to conducting measurements.

LL-37 Modification of PEMs by Physisorption and Chemical Immobilization: The physisorption of LL-37 onto COL/HA PEMs was performed on both PTFE-adherent and detached PEMs. PEMs were placed in 12-well plates and hydrated with PBS (1X) for 30 min. LL-37 solution at the appropriate concentration $(2 \mu \mathrm{M}, 8 \mu \mathrm{M}, 16 \mu \mathrm{M})$ was added to PEMs and rinsed after 30 min of peptide exposure.

LL-37 was covalently immobilized on PEMs using carbodiimide chemistry [27]. Briefly, PEMs were hydrated in PBS (1X) for 30 min. 1-ethyl-3-[3-dimethyl aminopropyl]carbodiimide (EDC) was added in a 10-fold molar excess to LL-37 in $0.1 \mathrm{M}$ 2-[morpholino] ethanesulfonic acid (MES) buffer at pH 6.0. N-hydroxysuccinimide (NHS) was added to the solution at a 10-fold molar excess to LL-37. The LL-37 solution was added to the hydrated PEMs and incubated for $2 \mathrm{~h}$ at room temperature.

Conjugation of a FITC Dye to LL-37: FITC dye was conjugated to the LL-37 peptide using a Pierce® FITC antibody labeling kit. Unconjugated FITC dye was separated from conjugated dye by passing the LL-37/FITC solution through a resin-filled spin column. The resulting solution was passed through a $0.2 \mu \mathrm{m}$ syringe filter to remove excess resin beads. FITC-conjugated LL-37 PEMs were imaged on a Nikon Eclipse TE2000-U microscope (Nikon, Linthicum MD). 
Zeta-potential: Zeta-potential measurements were conducted on PEMs using a SurPASS electrokinetic analyzer (Anton Paar, Ashland, VA) equipped with a clamping cell. A NaCl $(0.05 \mathrm{M})$ solution was passed through the channel separating PEM samples at a pressure of 200 mbar to obtain pressure-potential curves. At least eight measurements were obtained per sample. Zeta potential values were calculated using a modified Smoluchowski equation (Equation 3).

Equation $3 \quad \zeta=\frac{d U}{d p} \frac{\eta}{\left(\varepsilon * \varepsilon_{0}\right)} K_{B}$

$\zeta=$ zeta potential $(\mathrm{mV}), \mathrm{dU} / \mathrm{dp}=$ slope of streaming potential versus differential pressure, $\eta=$ electrolyte viscosity, $\varepsilon=$ dielectric coefficient of the $\mathrm{NaCl}$ solution, $\varepsilon_{0}=$ vacuum permittivity $\left(8.854 \times 10^{-12} \mathrm{~F} / \mathrm{m}\right)$, and $\mathrm{K}_{\mathrm{B}}=$ conductivity of $\mathrm{NaCl}[28,29]$.

Release of LL-37 from PEMs: The release of FITC-conjugated LL-37 was monitored over a $96 \mathrm{~h}$ period. The peptide-modified films were placed in $2 \mathrm{~mL}$ of Lysogeny broth (LB) and the fluorescence intensity was measured (SpectraMax M2 UV/vis spectrophotometer) at $495 \mathrm{~nm}$ at regular time intervals. Intensity values were converted to LL-37 concentrations using a calibration curve.

E. coli Culture: Gram-negative E. coli, strain DH10B was used for all bacterial studies. E. coli was seeded on a LB agar plate and allowed to grow at $37{ }^{\circ} \mathrm{C}$ overnight. The composition of LB was $10 \mathrm{~g} \mathrm{~L}^{-1} \mathrm{NaCl}, 5 \mathrm{~g} \mathrm{~L}^{-1}$ yeast extract, and $10 \mathrm{~g} \mathrm{~L}^{-1}$ tryptone; $1.5 \%$ agar powder was added to the LB for agar plates. An inoculum was then prepared in 5 $\mathrm{mL}$ LB and allowed to grow at $37^{\circ} \mathrm{C}$ with agitation for $5 \mathrm{~h}$ to reach the late-log phase. The inoculum was diluted to obtain an optical density at $600 \mathrm{~nm}\left(\mathrm{OD}_{600}\right)$ of 0.3 . The $O D$ measurements were conducted on a SpectraMax M2 UV/vis spectrophotometer with the solution placed in a cuvette $(1.5 \mathrm{~mL} ; 1 \mathrm{~cm}$ path-length). Measurements on bacterial cultures were conducted $24 \mathrm{~h}$ and $48 \mathrm{~h}$ post-seeding. 
Minimum Inhibitory Concentration (MIC) of LL-37: Bacteria were cultured on an LB agar plate overnight. An inoculum was prepared either in LB or Mueller-Hinton (MH) broth and diluted to $\mathrm{OD}_{600}=0.050$ according to the Clinical and Laboratory Standards Institute [30]. Equal volumes of LL-37 and bacterial inoculum were added to a well plate. The peptide concentrations ranged from 0-16 $\mu \mathrm{M}$. Fresh broth and fresh inoculum $(0 \mu \mathrm{M}$ LL-37) served as negative and positive controls, respectively. $\mathrm{OD}_{600}$ measurements were conducted at time $\mathrm{t}=0$ and $18 \mathrm{~h}$ using a SpectraMax M2 UV/vis spectrophotometer. The MIC was the LL-37 concentration where there was no change in $O D_{600}$ between $t=0$ and $18 \mathrm{~h}$.

Bacterial Adhesion Studies: Detachable COL/HA PEMs were placed in 12-well tissue culture polystyrene (TCPS) plates. PEMs were placed in wells with either the COL or HA $\mathrm{PE}$ in contact with bacteria to determine if chemical and structural variations on the PEM surface could alter bacterial adhesion. LL-37 solutions of varying concentrations were physisorbed on the hydrated PEMs. Bacteria were added to each well $(0.5 \mathrm{~mL}$, $\mathrm{OD}_{600}=0.300$ ) and incubated at $37^{\circ} \mathrm{C}$. Bacteria seeded on TCPS and unmodified PEMs served as controls. Spent broth was removed after $24 \mathrm{~h}$ of incubation and PEMs were rinsed with fresh broth to remove non-adherent cells. Fresh LB was added to the $48 \mathrm{~h}$ time-point cultures.

To detect the effects of serum, studies were conducted by suspending the bacterial inoculum in LB broth that contained $10 \% \mathrm{v} / \mathrm{v}$ fetal bovine serum (FBS; Life Technologies). Bacterial suspensions in FBS/LB mixtures were diluted to a $0 D_{600}$ value of 0.3 and seeded on LL-37 modified PEMs. Sample size was $n=3$ for all experiments.

Imaging on adherent bacterial cultures was performed using a LIVE/DEAD® BacLight ${ }^{\mathrm{TM}}$ bacterial viability kit following the manufacturer's recommended procedures. 
Fluorescence images were obtained at $530 \mathrm{~nm}$ (live) and $630 \mathrm{~nm}$ (dead). The surface area covered by live/dead bacteria was calculated using NIS-Elements Advanced Research software (Nikon, Linthicum, MD). $\mathrm{OD}_{600}$ and live/dead measurements were also conducted on aliquots containing non-adherent bacteria. The ratio of live/dead cells was calculated and calibrated to a standard curve.

Neutralizing a Bacterial Culture: These studies were performed with PEMs that had not been detached from PTFE substrates. Bacteria $\left(0.5 \mathrm{~mL}, \mathrm{OD}_{600}=0.300\right)$ were seeded on 12-well TCPS plates and incubated at $37^{\circ} \mathrm{C}$ for $24 \mathrm{~h}$. PEMs, or clean PTFE (control), were subsequently placed above the bacterial layer and incubated for $24 \mathrm{~h}$ or $48 \mathrm{~h}$. At the designated time-point, the PEM or PTFE was removed. Live/Dead staining was performed on the underlying bacterial layer as previously described.

Isolation and Culture of Rat Hepatocytes: Primary hepatocytes were isolated from female Lewis rats (175-200 g; Harlan Laboratories, Indianapolis, IN) using a two-step in situ collagenase perfusion technique [25, 31]. The surgical excision of rat livers and animal care procedures were approved by and in accordance with Virginia Tech's Institutional Animal Care and Use Committee. Hepatocyte viabilities ranged from 95$98 \%$ as determined by trypan blue exclusion. A typical surgery resulted in 150-200 million hepatocytes. For studies on LL-37 modified PEMs, the films were hydrated and sterilized by exposure to germicidal UV for $60 \mathrm{~min}$. Hepatocytes were seeded at a density of $0.6 \times 10^{6}$ cells per well in $0.5 \mathrm{~mL}$ hepatocyte-specific medium [31, 32]. Cultures were maintained in hepatocyte-specific media containing DMEM supplemented with $10 \% \mathrm{v} / \mathrm{v}$ heat-inactivated fetal bovine serum, $100 \mathrm{U} \mathrm{ml}^{-1}$ penicillin-streptomycin, 0.5 $\mathrm{IU} \mathrm{ml}{ }^{-1}$ insulin, $14.3 \mathrm{ng} \mathrm{ml}^{-1}$ glucagon, $20 \mathrm{ng} \mathrm{mL}^{-1}$ epidermal growth factor and $7.6 \mathrm{\mu g} \mathrm{ml}^{-1}$ hydrocortisone. Spent medium was collected every $24 \mathrm{~h}$ and stored at $-80^{\circ} \mathrm{C}$. Cultures were maintained in a $10 \% \mathrm{CO}_{2}, 37^{\circ} \mathrm{C}$ humidified incubator. 
Albumin Immunostaining: Hepatocyte cultures were fixed with $2 \% \mathrm{w} / \mathrm{v}$ glutaraldehyde/PBS. The cultures were sequentially exposed to $0.1 \% \mathrm{w} / \mathrm{v}$ sodium borohydride, $0.1 \% \mathrm{v} / \mathrm{v}$ Triton $\mathrm{X}-100$ and a $1 \% \mathrm{w} / \mathrm{v}$ bovine serum albumin (BSA/PBS) blocking solution. Cultures were incubated with a sheep-anti rat FITC-conjugated albumin antibody (ab53435; Abcam, Cambridge, MA). Cells were maintained in 25\% v/v glycerol and imaged on a Nikon Eclipse TE2000-U microscope.

\section{Statistical Analysis}

All analyses were conducted with a sample size of $n \geq 3$. A two-tailed $t$-test $(\alpha<0.05)$ was used to determine statistical significance. Bonferroni's correction was applied to correct for multiple hypotheses testing.

\section{RESULTS}

The Assembly and Characterization of Detachable PEMs: The COL and HA concentrations, number of bilayers and crosslinking conditions were varied to obtain detachable and usable PEMs (Supplementary Table 1). Our goal was to obtain detachable PEMs with thicknesses mimicking basement membranes found in vivo and that could also be handled with ease. The conditions that resulted in detachable $15 \mathrm{BL}$ COL/HA PEMs were obtained by using $1.5 \mathrm{mg} \mathrm{mL}^{-1} \mathrm{COL}$ and $\mathrm{HA}$, and cross-linked with glutaraldehyde for $30 \mathrm{~s}$ (Figure 2A). The stability of these films was monitored in PBS (1X) at $37{ }^{\circ} \mathrm{C}$ over 14 days. On days 3,7 and 14 the mass retention was $98.0 \pm 0.9 \%$ $(n=3), 94.6 \pm 1.5 \%(n=9)$ and $86.9 \pm 0.1 \%(n=6)$, respectively. Since all bacterial experiments were completed within $48 \mathrm{~h}$, the mass loss was approximately $2.0 \%$. PEMs exhibited dry and hydrated thicknesses of $2.1 \pm 0.6 \mu \mathrm{m}(n=38)$ and $3.3 \pm 0.6 \mu \mathrm{m}(n=62)$, respectively. Hydrated film thickness was approximately 1.6-fold higher than dry films 
indicating swelling of the PEM. The observed increase in PEM thickness upon hydration is consistent with previous studies on multilayers composed of biopolymers [25].

The YM of dry and hydrated PEMs was found to be $32.5 \pm 7.3 \mathrm{MPa}(n=9)$ and $128.6 \pm$ $24.4 \mathrm{kPa}(n=18)$, respectively. The hydrated modulus of these films mimics the elastic modulus of several tissues found in vivo [33]. AFM images of the surfaces of hydrated PEMs depict a highly porous film with an average roughness of $158.7 \pm 45.2 \mathrm{~nm}$ ( $n=3$ PEMs, 3 measurements/PEM) and a peak to valley ratio of $1.18 \pm 0.47 \mu \mathrm{m}$ (Figure 2B). The optical transmittance between $400-900 \mathrm{~nm}$ was found to range between $74.5-85.6 \%$ for dry multilayers $(n=10)$ and $85.8-94.6 \%$ for hydrated films ( $n=10)$ (Figure 2C). Zeta potential values on unmodified PEMs ranged from approximately -26 up to $-30 \mathrm{mV}$. PEMs with HA as the terminating layer exhibited a slightly lower negative potential in contrast to multilayers with $\mathrm{COL}$ as the final layer (Figure 2D).

Properties of LL-37 Modified PEMs: Upon physisorbing LL-37, the zeta potential values dropped to approximately $-4 \mathrm{mV}$ across all input concentrations of the AMP (Figure 2D). There was no statistical significance between COL and HA terminating LL37-modified PEMs. When the AMP was chemically immobilized, there was a steady increase (lower negative values) in the zeta potential as a function of input LL-37 concentration. HA terminating PEMs exhibited a significantly higher zeta potential compared to $\mathrm{COL}$ terminating PEMs (Figure 2E). These trends led to the use of HAterminating PEMs in bacterial studies.

FITC-conjugated LL-37 was used to detect the presence of the AMP on the surface of PEMs as well as to quantify the concentration of peptide released into the aqueous medium over a $96 \mathrm{~h}$ period. FITC-conjugated LL-37 was detected across the entire surface area of PEMs when the input concentrations were $8 \mu \mathrm{M}$ and $16 \mu \mathrm{M}$ (Figure 3A- 
H). The fluorescent intensity of FITC-LL-37 was significantly higher at these concentrations when the AMP was chemically immobilized indicating higher concentrations of the peptide (Figure $\mathbf{3 C}, \mathrm{D}, \mathrm{G}$ and $\mathrm{H}$ ).

The release of LL-37 from physisorbed PEMs over a $96 \mathrm{~h}$ period indicated sustained release of LL-37 into the media over time (Figure 3I). When LL-37 was chemically conjugated to PEMs, there was virtually no release of the AMP over $96 \mathrm{~h}$ (Figure 3J).

Antimicrobial Properties of COL/HA PEMs: In order to seed bacteria in the log phase, the growth profile for $E$. coli $\mathrm{DH} 10 \mathrm{~B}$ was determined by monitoring $\mathrm{OD}_{600}$ values (Supplementary Figure 1). The transition point between the log and stationary phases of growth was determined to be $6.53 \pm 0.31 \mathrm{~h}$. Therefore an inoculation period of $5 \mathrm{~h}$ was chosen to ensure that the bacteria would be in the log phase when seeded for experiments. The MIC of LL-37 for the DH10B strain of E. coli was determined by exposing bacteria to LL-37 in solution. The MIC for DH10B was found to be $8 \mu \mathrm{M}$ in LB and MH broth (Figure 4A, Supplementary Figure 2). Therefore in subsequent studies, concentrations of $2 \mu \mathrm{M}(25 \% \mathrm{MIC}), 8 \mu \mathrm{M}(\mathrm{MIC})$, and $16 \mu \mathrm{M}(200 \% \mathrm{MIC})$ were used to determine the antimicrobial effect of LL-37. Based on the release profile of LL-37 when physisorbed on PEMs (Figure 3l), at $24 \mathrm{~h}$, the percentage of LL-37 released into the broth was approximately $2 \%, 7.5 \%$ and $47 \%$ of the MIC at an input peptide concentration of $2 \mu \mathrm{M}, 8 \mu \mathrm{M}$ and $16 \mu \mathrm{M}$, respectively. At $48 \mathrm{~h}$, the percentage of LL-37 released into the broth was approximately $15 \%, 64 \%$ and $110 \%$ of the MIC at an input peptide concentration of $2 \mu \mathrm{M}, 8 \mu \mathrm{M}$ and $16 \mu \mathrm{M}$, respectively.

The COL/HA PEMs were first tested for their ability to prevent adhesion of bacteria when exposed to a solution containing E. coli (Figure 4B-J). Interestingly, at $24 \mathrm{~h}$, the surface area covered by live bacteria for unmodified PEMs was approximately $40 \%$ lower on HA 
terminating multilayers $(15.9 \pm 0.1 \%$ area covered) than TCPS $(26.7 \pm 2.3 \%$ area covered) (Figure 5A). In contrast, there was no difference between TCPS and COLterminating unmodified PEMs $(26.6 \pm 10.4 \%$ area covered). This result suggests that the HA-terminating PEMs were more effective in reducing bacterial adhesion. There was an additional decrease in the surface coverage of live bacteria in contact with physisorbed LL-37 PEMs (Figure 5A). The surface area covered by live bacteria reduced to $11.5 \pm 2.1 \%(2 \mu \mathrm{M}), 6.9 \pm 0.2 \%(8 \mu \mathrm{M})$ and $2.3 \pm 1.0 \%(16 \mu \mathrm{M})$. At these same input concentrations of LL37, the corresponding surface coverage values on COLterminating PEMs was $24.3 \pm 4.3 \%(2 \mu \mathrm{M}), 13.2 \pm 4.2 \%(8 \mu \mathrm{M})$, and $7.1 \pm 3.2 \%(16 \mu \mathrm{M})$. Over a $48 \mathrm{~h}$ period, the surface occupied by bacteria did not change for input AMP concentrations of 8 and $16 \mu \mathrm{M}$. However, HA-terminating PEMs continued to be more effective in reducing bacterial adhesion. These trends, along with the previous zeta potential studies, suggest that the anionic HA may assist with preventing bacterial adhesion due to electrostatic repulsion. For this reason, further testing on repelling bacterial adhesion was conducted only on HA-terminating PEMs.

When LL-37 was immobilized on the surface of COL/HA PEMs, (Figure 5B) a concentration dependent decrease in live bacteria was observed, with $16 \mu \mathrm{M}$ films exhibiting approximately only $2.9 \pm 1.0 \%$ of the surface covered with live bacteria. There was no change in the surface area occupied by live bacteria between $24 \mathrm{~h}$ and $48 \mathrm{~h}$ for AMP-modified PEMs in contrast to bacterial proliferation observed on TCPS. This trend indicated that the immobilized LL-37 was effective in preventing bacterial proliferation over this time period. 
Since LL-37 was released when it was physically adsorbed on COL/HA PEMs, the number of live bacteria in the broth was also monitored over a $48 \mathrm{~h}$ period. This enabled testing the antimicrobial activity of the peptide after it was released into the broth. The number of live cells in the broth was calculated based on $\mathrm{OD}_{600}$ and fluorescent imaging (Supplementary Figure 3) and is reported relative to the initial number seeded. At $24 \mathrm{~h}$, all bacterial solutions in contact with LL-37 modified PEMs (physisorbed) exhibited statistically lower numbers of live cells. Over a $48 \mathrm{~h}$ period, there was a significant reduction in the number of bacteria with approximately only $30 \%$ live cells. Based on the release profile for LL-37 (when physisorbed) $<20 \%$ of the AMP is released into the broth by $24 \mathrm{~h}$, not resulting in significant bacterial death. In contrast, at $48 \mathrm{~h}$, the number of live bacteria in solution doubled when the AMP was chemically immobilized. Since no LL-37 was released from these multilayers, the planktonic bacteria survived and proliferated.

The effect of serum was investigated when LL-37 was either physisorbed or immobilized on PEMs. First, bacterial surface coverage on TCPS was measured and was found to be $32.0 \pm 8.8 \%$ (serum-free) and $32.1 \pm 6.3 \%$ (serum). These results confirmed that the presence of serum did not change bacterial adhesion on TCPS. Next, the surface area of PEMs covered by $E$. coli was measured at $8 \mu \mathrm{M}$ of LL-37 in the presence of serum, and compared to un-modified multilayers. When LL-37 was immobilized, the decrease in bacterial surface coverage was approximately $55 \%$ (serum-free) and $62 \%$ (serum). The decrease in bacterial surface coverage was approximately $47 \%$ (serum-free) and $62 \%$ (serum) for physisorbed PEMs. These data indicate that the addition of $10 \%$ FBS in LB broth did not affect the activity of the AMP. 
In order to determine if LL-37 modified PEMs could kill bacteria if placed in close contact with an existing bacterial culture, AMP-modified multilayers were placed above a layer of E. coli. In these experiments, E. coli were cultured on TCPS and an AMP-modified PEM was placed above the bacterial layer. After $24 \mathrm{~h}$ and $48 \mathrm{~h}$, the PEMs were removed and the underlying bacterial cultures were imaged for dead bacteria to determine the effectiveness of the AMP-modified PEMs (Figure 6A-I). For the physisorbed films, the 8 $\mu \mathrm{M}$ and $16 \mu \mathrm{M}$ modified films exhibited statistically significant decreases in $E$. coli viability compared to TCPS and unmodified controls (Figure 6J). The $16 \mu \mathrm{M}$ films resulted in a reduction of the area covered by bacteria (cultured on a TCPS substrate) from approximately $50 \%$ to $8 \%$. Even after $48 \mathrm{~h}$, the area covered by live bacteria did not change for PEMs modified with $16 \mu \mathrm{M}$ of LL-37. These findings demonstrate that the concentration of the LL-37 is an important factor in the neutralization of $E$. coli cultures, especially over a $48 \mathrm{~h}$ time period. Immobilized LL-37-PEMs that were in contact with $E$. coli cultures also resulted in statistically significant lower microbial viabilities than TCPS and unmodified multilayers (Figure 6K). For all input concentrations of LL-37, PEMs with immobilized AMPs were more efficient in neutralizing an existing E. coli layer. These trends prevailed over the $48 \mathrm{~h}$ observation period.

Interaction of Primary Rat Hepatocytes and LL-37 Modified PEMs: Primary rat hepatocytes were cultured on the LL-37 modified PEMs to determine if the AMP caused cytotoxicity. Hepatocytes were chosen since they are typically very sensitive to their environment and exhibit rapidly declining function if the biomaterial is not compatible. Phase contrast images of hepatocytes cultured on LL-37 modified PEMs are shown in Figure 7A-H. Hepatocytes exhibited a typical polygonal morphology across all concentrations of LL-37 when the AMP was physisorbed. However, when LL-37 was immobilized, these cells exhibited a more rounded morphology at $16 \mu \mathrm{M}$ LL-37. 
Hepatocytes seeded on immobilized PEMs exhibited cytoplasmic albumin on all LL-37 modified PEMs suggesting no change in protein production or localization as a function of peptide concentration (Figure 7I-P).

Albumin and urea values in the culture medium were measured since they are two markers that are characteristic of hepatocyte function. These measurements were conducted on spent culture medium obtained after $48 \mathrm{~h}$ in culture and normalized to the number of hepatocytes seeded $\left(6 \times 10^{5}\right.$ cells). A $48 \mathrm{~h}$ time-point was selected since it correlated to the culture period for the bacterial studies. Albumin levels from the ELISA assay were consistently lower when LL-37 was immobilized versus physically adsorbed on PEMs (Figure 7Q). However, there was no significant difference between $2 \mu \mathrm{M}, 8 \mu \mathrm{M}$ or $16 \mu \mathrm{M}$ LL-37 indicating that the immobilization process and not LL-37 may have resulted in lower albumin secretion. All urea values for physisorbed and immobilized PEM samples were within $\pm 20 \%$ indicating that concentrations of LL-37 up to $16 \mu \mathrm{M}$ did not have a significant impact on urea levels (Figure 7R). Taken together, these trends indicated that hepatocyte morphology and function were better maintained when cultured on PEMs with physisorbed LL-37. These results were attributed to a combination of changes occurring to the PEM upon immobilization and the fact that LL37 was released from physisorbed PEMs.

\section{DISCUSSION}

$\mathrm{COL}$ is the most abundant protein in the body while HA is found in connective tissues. Furthermore, HA has been shown to exhibit antimicrobial properties against multiple bacterial strains [22]. Taken together, the natural, biocompatible and inherently antimicrobial properties of these PEMs makes them ideal for studying pathogen-tissue interactions. A significant advance in this study is the ability to assemble detachable 
PEMs composed of $\mathrm{COL}$ and $\mathrm{HA}$ with physical properties that match biological membranes and tissues. In the past, collagen-HA PEMs reported in literature were assembled and used while they remained adherent to a substrate [34, 35]. Such nondetachable ECM-based PEMs are limited in their biological applications since the substrate was usually a silicon wafer, quartz or glass.

Antimicrobial PEMs have been assembled by the incorporation of conventional antibiotics and antiseptics [36-38] or silver nanoparticles [39]. Other studies have reported PEMs assembled with innately antimicrobial PEs such as chitosan, HA and Nalkylated poly(ethylenimine) [40-43]. Reports on modifying PEMs using AMPs and other antibacterial agents have been conducted only on non-detachable multilayers [40-46].

The ease of fabrication, the ability to tune chemical and mechanical properties, and the composition of ECM-based COL/HA PEMs, make them ideal for applications such as basement membranes [25, 31, 47] scaffolds and coatings [48-50]. Even in the absence of an antibacterial agent, HA-terminating PEMs reduced bacterial adhesion by approximately $40 \%$. This result can be attributed to the hydrated structure of HA and its interactions with bacteria. A previous study demonstrated that $\mathrm{HA}$ alone reduced bacterial adhesion by up to $76 \%$ [22].

The incorporation of LL-37 significantly prevented bacterial adhesion over a $48 \mathrm{~h}$ period. Physically adsorbing LL-37 on PEMs resulted in two beneficial outcomes. First, bacterial adhesion on the PEMs was reduced compared to TCPS. Second, the sustained release of the active peptide killed planktonic bacteria. This prevented bacteria present in the broth from adhering to the PEMs over a $48 \mathrm{~h}$ period. The combination of two antimicrobial mechanisms results in materials that exhibit significant potential as 
antimicrobial coatings for biomedical applications. The immobilization of LL-37 resulted in PEMs that could effectively kill E. coli in a mature culture. Approximately $3 \%$ of the bacterial layer remained at $24 \mathrm{~h}$ and no additional growth was detected over a $48 \mathrm{~h}$ period. In this study, the percentage of a PEM surface area covered by bacteria was reported instead of colony forming units (CFU. $\mathrm{mL}^{-1}$ ) since surface coverage could be measured directly by microscopy. For bacterial concentrations in the broth, changes in actual bacterial numbers are provided. These trends suggest that immobilizing an AMP on a COL/HA PEM may be an effective strategy in neutralizing and existing bacterial culture. The presence of serum did not decrease the antimicrobial activity of LL-37. In fact, there was a small improvement, which was interesting and merits deeper investigation. Future studies will focus upon the use of LL-37 modified thin films in combating bacterial biofilms and Gram-positive bacterial strains.

\section{CONCLUSION}

The retention of water in the hydrated state resulted in COL/HA PEMs in lowering bacterial adhesion by $40 \%$. The incorporation of LL-37 lead to PEMs that significantly repelled microbial adhesion. The presence of LL-37 in PEMs resulted in three separate antimicrobial mechanisms. The LL-37-modfied PEMs prevented bacterial adhesion, killed bacteria in broth and neutralized an E. coli culture. More importantly, hepatocyte function and morphology were maintained at the MIC of the AMP. In the future, investigations will focus upon the antimicrobial properties of LL-37 when administered to bacteria that are found in wounds such as Staphylococcus aureus (S. aureus) and Pseudomonas aeruginosa (P. aeruginosa). It will also be of interest to study if exposure to LL-37 could result in AMP-resistant bacteria. LL-37 is considered a pleiotropic AMP, since it can also kill fungi and viruses [15]. Future studies will focus on the anti-viral and 
anti-fungal properties of LL-37 modified PEMs in order to fully harness the broadspectrum properties of this AMP.

\section{ACKNOWLEDGEMENTS}

We gratefully acknowledge financial support from the National Science Foundation (NSF DBI-1062380 and DMR 1410341). We also acknowledge financial support from the Institute for Critical Technologies and Applied Sciences and the Computational Tissue Engineering Interdisciplinary Graduate Education Program at Virginia Tech. We thank Dr. B. Mukhopadhyay and Dr. D. Susanti (Department of Biochemistry, Virginia Tech) for their guidance on bacterial culture techniques. 


\section{REFERENCES}

[1] Fischbach MA, Walsh CT. Antibiotics for emerging pathogens. Science 2009;325:108993.

[2] Li P, Zhou C, Rayatpisheh S, Ye K, Poon YF, Hammond PT, et al. Cationic peptidopolysaccharides show excellent broad-spectrum antimicrobial activities and high selectivity. Advanced materials 2012;24:4130-7.

[3] Palermo EF, Vemparala S, Kuroda K. Antimicrobial Polymers: Molecular Design as Synthetic Mimics of Host-Defense Peptides. In: Scholz C, Kressler J, editors. Tailored Polymer Architectures for Pharmaceutical and Biomedical Applications. Washington DC: American Chemical Society; 2013.

[4] French GL. The continuing crisis in antibiotic resistance. International journal of antimicrobial agents 2010;36 Suppl 3:S3-7.

[5] Peleg AY, Hooper DC. Hospital-acquired infections due to gram-negative bacteria. The New England journal of medicine 2010;362:1804-13.

[6] Kokryakov VN, Harwig SS, Panyutich EA, Shevchenko AA, Aleshina GM, Shamova OV, et al. Protegrins: leukocyte antimicrobial peptides that combine features of corticostatic defensins and tachyplesins. FEBS letters 1993;327:231-6.

[7] Schittek B, Hipfel R, Sauer B, Bauer J, Kalbacher H, Stevanovic S, et al. Dermcidin: a novel human antibiotic peptide secreted by sweat glands. Nature immunology 2001;2:1133-7.

[8] Zasloff M. Antimicrobial peptides of multicellular organisms. Nature 2002;415:389-95. [9] Barlow PG, Findlay EG, Currie SM, Davidson DJ. Antiviral potential of cathelicidins. Future microbiology 2014;9:55-73.

[10] Jenssen H, Hamill P, Hancock RE. Peptide antimicrobial agents. Clinical microbiology reviews 2006;19:491-511.

[11] Gallo RL, Murakami M, Ohtake T, Zaiou M. Biology and clinical relevance of naturally occurring antimicrobial peptides. The Journal of allergy and clinical immunology 2002;110:823-31.

[12] Sato H, Feix JB. Peptide-membrane interactions and mechanisms of membrane destruction by amphipathic alpha-helical antimicrobial peptides. Biochimica et biophysica acta 2006;1758:1245-56.

[13] Sengupta D, Leontiadou H, Mark AE, Marrink SJ. Toroidal pores formed by antimicrobial peptides show significant disorder. Biochimica et biophysica acta 2008;1778:2308-17.

[14] Zaiou M, Nizet V, Gallo RL. Antimicrobial and protease inhibitory functions of the human cathelicidin (hCAP18/LL-37) prosequence. The Journal of investigative dermatology 2003;120:810-6.

[15] Vandamme D, Landuyt B, Luyten W, Schoofs L. A comprehensive summary of LL-37, the factotum human cathelicidin peptide. Cellular immunology 2012;280:22-35.

[16] Beaumont PE, Hsin-Ni L, Davidson DJ. LL-37: An Immunomodulatory Antimicrobial Host Defense Peptide. In: Heimstra PS, Zaat SAJ, editors. Antimicrobial Peptides and Innate Immunity. Progress in Inflammation Research: Springer Basel; 2013.

[17] Oren Z, Lerman JC, Gudmundsson GH, Agerberth B, Shai Y. Structure and organization of the human antimicrobial peptide LL-37 in phospholipid membranes: relevance to the molecular basis for its non-cell-selective activity. The Biochemical journal 1999;341 ( Pt 3):501-13.

[18] Palermo EF, Lee DK, Ramamoorthy A, Kuroda K. Role of cationic group structure in membrane binding and disruption by amphiphilic copolymers. The journal of physical chemistry B 2011;115:366-75. 
[19] Mizutani M, Palermo EF, Thoma LM, Satoh K, Kamigaito M, Kuroda K. Design and synthesis of self-degradable antibacterial polymers by simultaneous chain- and step-growth radical copolymerization. Biomacromolecules 2012;13:1554-63.

[20] Engler AC, Shukla A, Puranam S, Buss HG, Jreige N, Hammond PT. Effects of side group functionality and molecular weight on the activity of synthetic antimicrobial polypeptides. Biomacromolecules 2011;12:1666-74.

[21] Ardizzoni A, Neglia RG, Baschieri MC, Cermelli C, Caratozzolo M, Righi E, et al. Influence of hyaluronic acid on bacterial and fungal species, including clinically relevant opportunistic pathogens. Journal of materials science Materials in medicine 2011;22:2329-38.

[22] Carlson GA, Dragoo JL, Samimi B, Bruckner DA, Bernard GW, Hedrick M, et al.

Bacteriostatic properties of biomatrices against common orthopaedic pathogens.

Biochemical and biophysical research communications 2004;321:472-8.

[23] Detzel CJ, Larkin AL, Rajagopalan P. Polyelectrolyte multilayers in tissue engineering.

Tissue engineering Part B, Reviews 2011;17:101-13.

[24] Larkin AL, Davis RM, Rajagopalan P. Biocompatible, detachable, and free-standing polyelectrolyte multilayer films. Biomacromolecules 2010;11:2788-96.

[25] Larkin AL, Rodrigues RR, Murali TM, Rajagopalan P. Designing a Multicellular

Organotypic 3D Liver Model with a Detachable, Nanoscale Polymeric Space of Disse. Tissue

engineering Part C, Methods 2013.

[26] Ford AJ, Jain G, Rajagopalan P. Designing a fibrotic microenvironment to investigate changes in human liver sinusoidal endothelial cell function. Acta biomaterialia

2015;24:220-7.

[27] Hermanson GT. Bioconjugate techniques. San Diego: Academic Press; 1996.

[28] Grant GG, Koktysh DS, Yun B, Matts RL, Kotov NA. Layer-by-layer assembly of collagen thin films: controlled thickness and biocompatibility. Biomedical Microdevices 2001;3:301-

6.

[29] Chan YM, Schweiss R, Werner C, Grunze M. Electrokinetic characterization of oligo- and poly(ethylene glycol)-terminated self-assembled monolayers on gold and glass surfaces.

Langmuir 2003;19:7380-5.

[30] Coyle MB, American Society for Microbiology. Manual of antimicrobial susceptibility testing. Washington, DC: American Society for Microbiology,; 2005. p. 1 CD-ROM.

[31] Kim Y, Larkin AL, Davis RM, Rajagopalan P. The design of in vitro liver sinusoid mimics using chitosan-hyaluronic acid polyelectrolyte multilayers. Tissue engineering Part A 2010;16:2731-41.

[32] Kim Y, Rajagopalan P. 3D hepatic cultures simultaneously maintain primary hepatocyte and liver sinusoidal endothelial cell phenotypes. PloS one 2010;5:e15456.

[33] Engler AJ, Sen S, Sweeney HL, Discher DE. Matrix elasticity directs stem cell lineage specification. Cell 2006;126:677-89.

[34] Johansson JA, Halthur T, Herranen M, Soderberg L, Elofsson U, Hilborn J. Build-up of collagen and hyaluronic acid polyelectrolyte multilayers. Biomacromolecules 2005;6:13539.

[35] Zhang J, Senger B, Vautier D, Picart C, Schaaf P, Voegel JC, et al. Natural polyelectrolyte films based on layer-by layer deposition of collagen and hyaluronic acid. Biomaterials 2005;26:3353-61.

[36] Agarwal A, Nelson TB, Kierski PR, Schurr MJ, Murphy CJ, Czuprynski CJ, et al. Polymeric multilayers that localize the release of chlorhexidine from biologic wound dressings.

Biomaterials 2012;33:6783-92.

[37] Fujie T, Saito A, Kinoshita M, Miyazaki H, Ohtsubo S, Saitoh D, et al. Dual therapeutic action of antibiotic-loaded nanosheets for the treatment of gastrointestinal tissue defects. Biomaterials 2010;31:6269-78. 
[38] Saito A, Miyazaki H, Fujie T, Ohtsubo S, Kinoshita M, Saitoh D, et al. Therapeutic efficacy of an antibiotic-loaded nanosheet in a murine burn-wound infection model. Acta biomaterialia 2012;8:2932-40.

[39] Agarwal A, Weis TL, Schurr MJ, Faith NG, Czuprynski CJ, McAnulty JF, et al. Surfaces modified with nanometer-thick silver-impregnated polymeric films that kill bacteria but support growth of mammalian cells. Biomaterials 2010;31:680-90.

[40] Wang BL, Ren KF, Wang HCJL, Ji J. Construction of Degradable Multilayer Films for Enhanced Antibacterial Properties. Acs Appl Mater Inter 2013;5:4136-43.

[41] Wong SY, Han L, Timachova K, Veselinovic J, Hyder MN, Ortiz C, et al. Drastically lowered protein adsorption on microbicidal hydrophobic/hydrophilic polyelectrolyte multilayers. Biomacromolecules 2012;13:719-26.

[42] Wong SY, Moskowitz JS, Veselinovic J, Rosario RA, Timachova K, Blaisse MR, et al. Dual functional polyelectrolyte multilayer coatings for implants: permanent microbicidal base with controlled release of therapeutic agents. Journal of the American Chemical Society 2010;132:17840-8.

[43] Wong SY, Li Q, Veselinovic J, Kim BS, Klibanov AM, Hammond PT. Bactericidal and virucidal ultrathin films assembled layer by layer from polycationic $\mathrm{N}$-alkylated polyethylenimines and polyanions. Biomaterials 2010;31:4079-87.

[44] Etienne 0, Picart C, Taddei C, Haikel Y, Dimarcq JL, Schaaf P, et al. Multilayer polyelectrolyte films functionalized by insertion of defensin: a new approach to protection of implants from bacterial colonization. Antimicrobial agents and chemotherapy 2004;48:3662-9.

[45] Rudra JS, Dave K, Haynie DT. Antimicrobial polypeptide multilayer nanocoatings. Journal of biomaterials science Polymer edition 2006;17:1301-15.

[46] Guyomard A. DE, Jouenne T.,Malandain J., Muller G., Glinel K. Incorporation of a Hydrophobic Antibacterial Peptide into Amphiphilic Polyelectrolyte Multilayers: A Bioinspired Approach to Prepare Biocidal Thin Coatings. Advanced Functional Materials 2008;18:758-65.

[47] Chaubaroux C, Vrana E, Debry C, Schaaf P, Senger B, Voegel JC, et al. Collagen-based fibrillar multilayer films cross-linked by a natural agent. Biomacromolecules 2012;13:212835 .

[48] Boura C, Muller S, Voegel JC, Schaaf P, Stoltz JF, Menu P. Behaviour of endothelial cells seeded on thin polyelectrolyte multilayered films: a new biological scaffold. Clinical hemorheology and microcirculation 2005;33:269-75.

[49] Rajagopalan P, Shen CJ, Berthiaume F, Tilles AW, Toner M, Yarmush ML. Polyelectrolyte nano-scaffolds for the design of layered cellular architectures. Tissue engineering 2006;12:1553-63.

[50] Thierry B, Winnik FM, Merhi Y, Silver J, Tabrizian M. Bioactive coatings of endovascular stents based on polyelectrolyte multilayers. Biomacromolecules 2003;4:1564-71. 


\section{Figure Captions:}

Figure 1. AMP interactions with bacterial membranes (A) Barrel stave model: peptides aggregate and insert into the lipid bilayer. Hydrophilic regions of AMP form the interior of pore. (B) Carpet model: AMPs disrupt bilayer by orienting parallel to membrane surface to form a 'carpet' layer. (C) Toroidal pore model: peptides aggregate and induce lipids to bend throughout the pore. The core of the pore is lined with hydrophilic regions of the AMP and lipid heads groups. (Hydrophobic regions = blue, Hydrophilic regions = orange).

Figure 2. (A) A detachable COL/HA PEM, scale bar $=1 \mathrm{~cm},(\mathbf{B})$ Surface topography of a hydrated COL/HA PEM measured by AFM, (C) Optical transmittance of dry and hydrated PEMs between 400-900 nm, Zeta potential for (D) physisorbed and (E) immobilized LL-37 modified and unmodified PEMs ( $n \geq 8)$ with either COL or HA as the terminating layer. Statistical significance $(p<0.05)$ when compared to $0 \mu \mathrm{M}\left({ }^{*}\right), 2 \mu \mathrm{M}(\#)$, $8 \mu \mathrm{M}(+)$.

Figure 3. FITC-conjugated LL-37 when physisorbed (A-D) or chemically immobilized (EH) on PEMs. Release profile for (I) physisorbed and (J) immobilized FITC-conjugated LL-37 modified PEMs over 96 h. No detectable LL-37 release indicated by \#.

Figure 4. (A) Difference in OD600 measurements between $\mathrm{t}=0 \mathrm{~h}$ and $\mathrm{t}=18 \mathrm{~h}$ to determine the MIC of E. coli strain DH10B. Merged fluorescence images of surfaces covered by bacteria on TCPS (B) on PEMs with physisorbed LL-37 (C-F), on PEMs with immobilized LL-37 (G-J), green = live bacteria and red = dead bacteria, Scale bar= 100 $\mu \mathrm{m}$.

Figure 5. Percentage of surface area covered coverage by live bacteria on (A) physisorbed and (B) immobilized LL-37 modified and unmodified PEMs and TCPS 
controls. The HA-terminating layer was in contact with bacteria $(n \geq 6)$. Statistical significance $(p<0.05)$ when compared to TCPS controls $\left(^{*}\right), 0 \mu \mathrm{M}(\#), 2 \mu \mathrm{M}(+)$, and $8 \mu \mathrm{M}$ (†).

Figure 6. Merged fluorescence images of surface coverage by bacteria on TCPS (A), on PEMs with physisorbed LL-37 (B-E), on PEMs with immobilized LL-37 (F-I), green = live bacteria and red $=$ dead bacteria, Scale bar $=100 \mu \mathrm{m}$. Percentage of surface area covered coverage by live bacteria on $(\mathbf{J})$ physisorbed and $(\mathbf{K})$ immobilized LL-37 modified and unmodified PEMs and TCPS controls. The HA-terminating layer was in contact with bacteria $(n \geq 3)$. Statistical significance $(p<0.05)$ when compared to TCPS controls $\left(^{*}\right), 0 \mu \mathrm{M}(\#), 2 \mu \mathrm{M}(+)$, and $8 \mu \mathrm{M}(\dagger)$.

Figure 7. Phase contrast images of hepatocytes cultured on modified PEMs for $24 \mathrm{~h}$, physisorbed LL-37 (A-D), immobilized LL-37 (E-H). Immunostaining for cytoplasmic albumin in hepatocytes cultured on HA-terminating COL/HA PEMs with (I-L) Physisorbed LL-37 and (M-P) Immobilized LL-37, Scale bar=100 $\mu \mathrm{m}$. Albumin (Q) and Urea $(\mathbf{R})$ secretion by hepatocytes cultured on HA-terminating COL/HA PEMs $(n=3)$. Statistical significance $(p<0.05)$ when hepatic function is compared between physisorbed and immobilized films $\left(^{*}\right)$. 


\section{B Bacterial Adhesion}

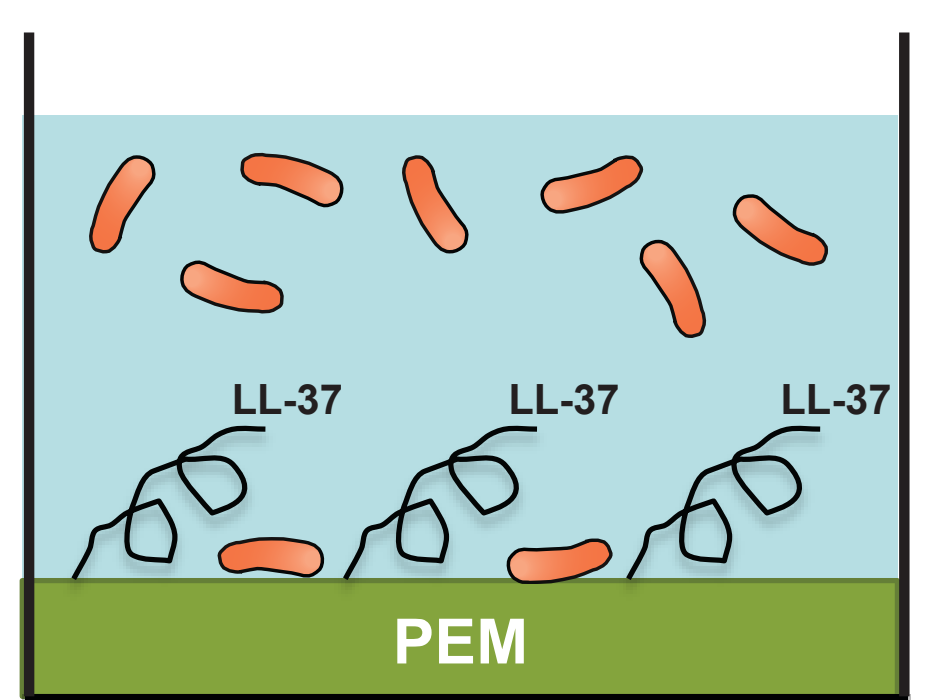

C Neutralizing Bacterial

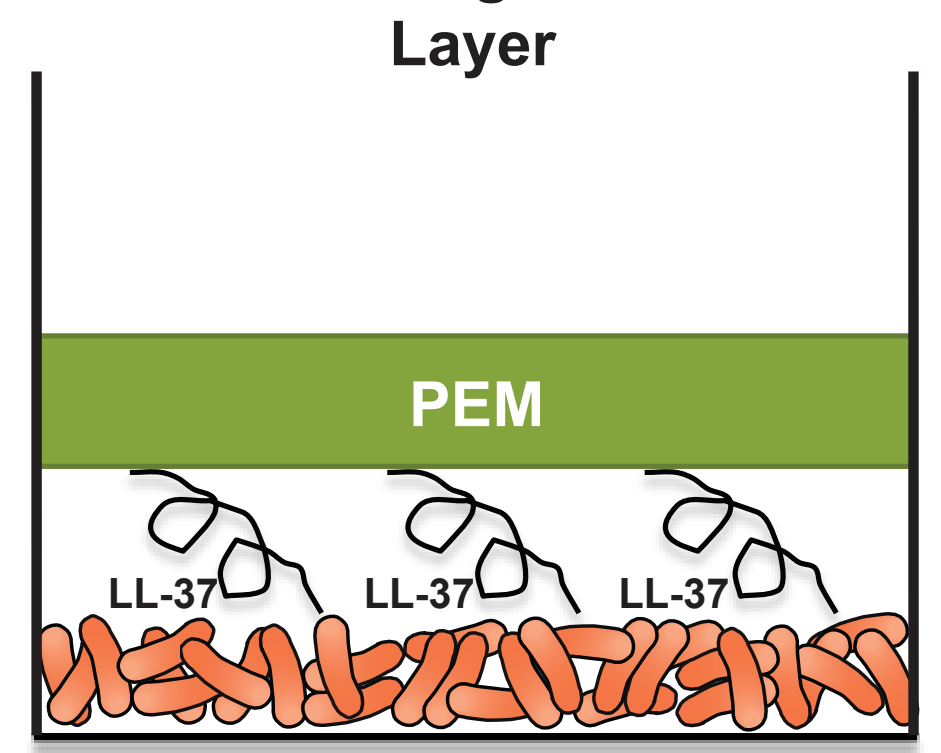

Graphical Abstract: (A) A detachable COL/HA PEM, (B) Schematic of E. coli in solution adhering to a LL-37 modified PEM, (C) Schematic of LL-35 modified PEMs neutralizing a layer of E. coli. 


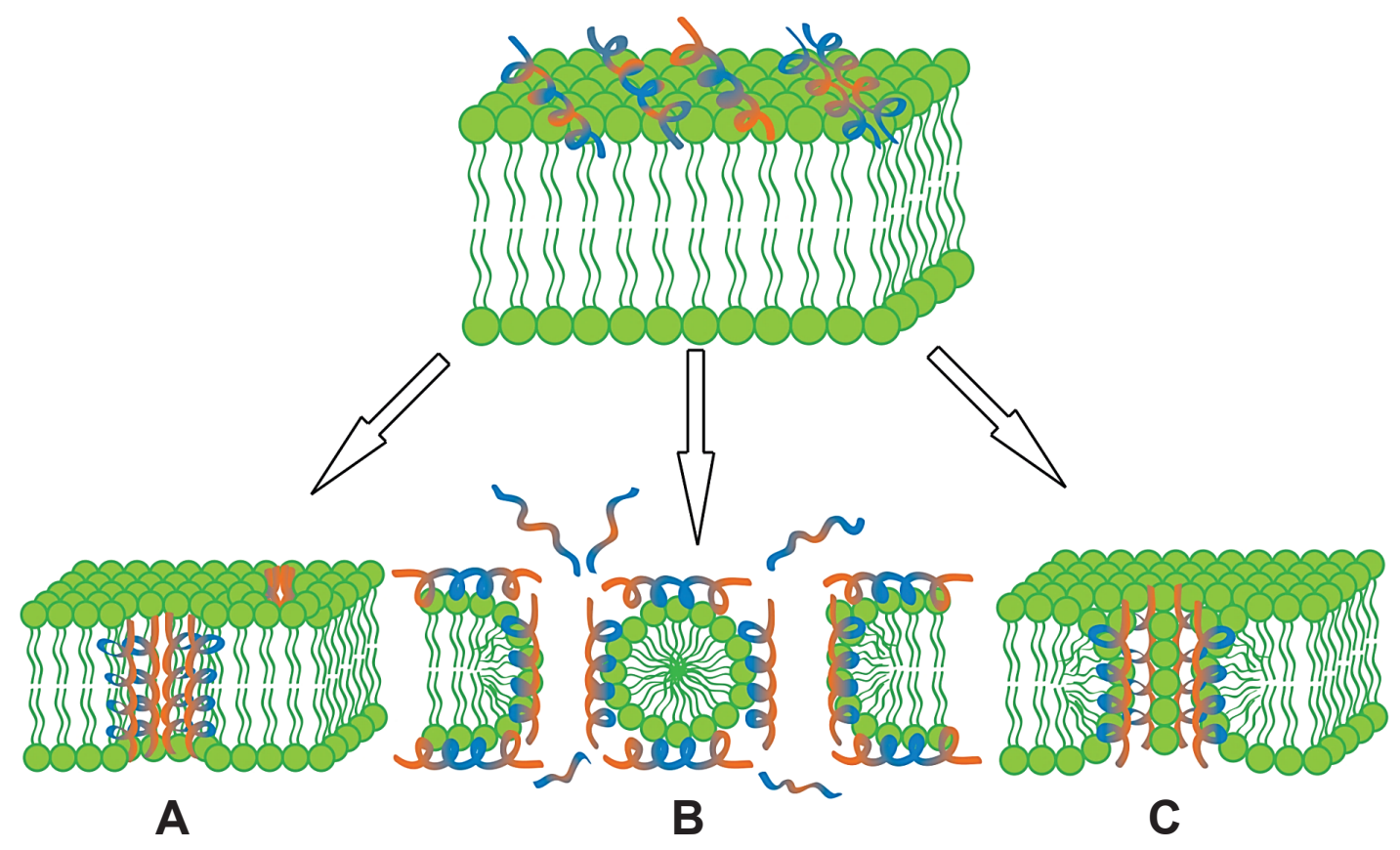

Figure 1 

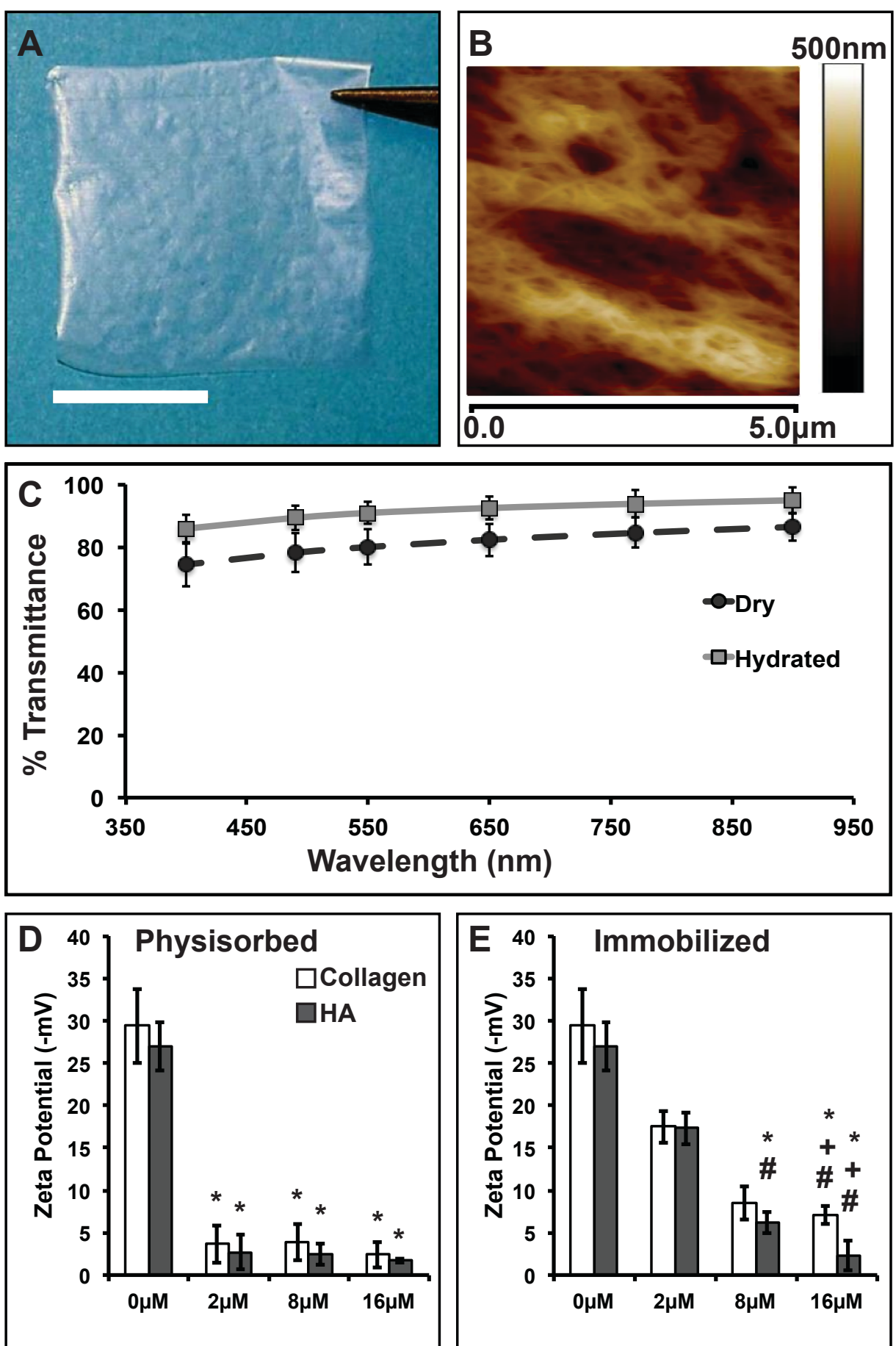

Figure 2 

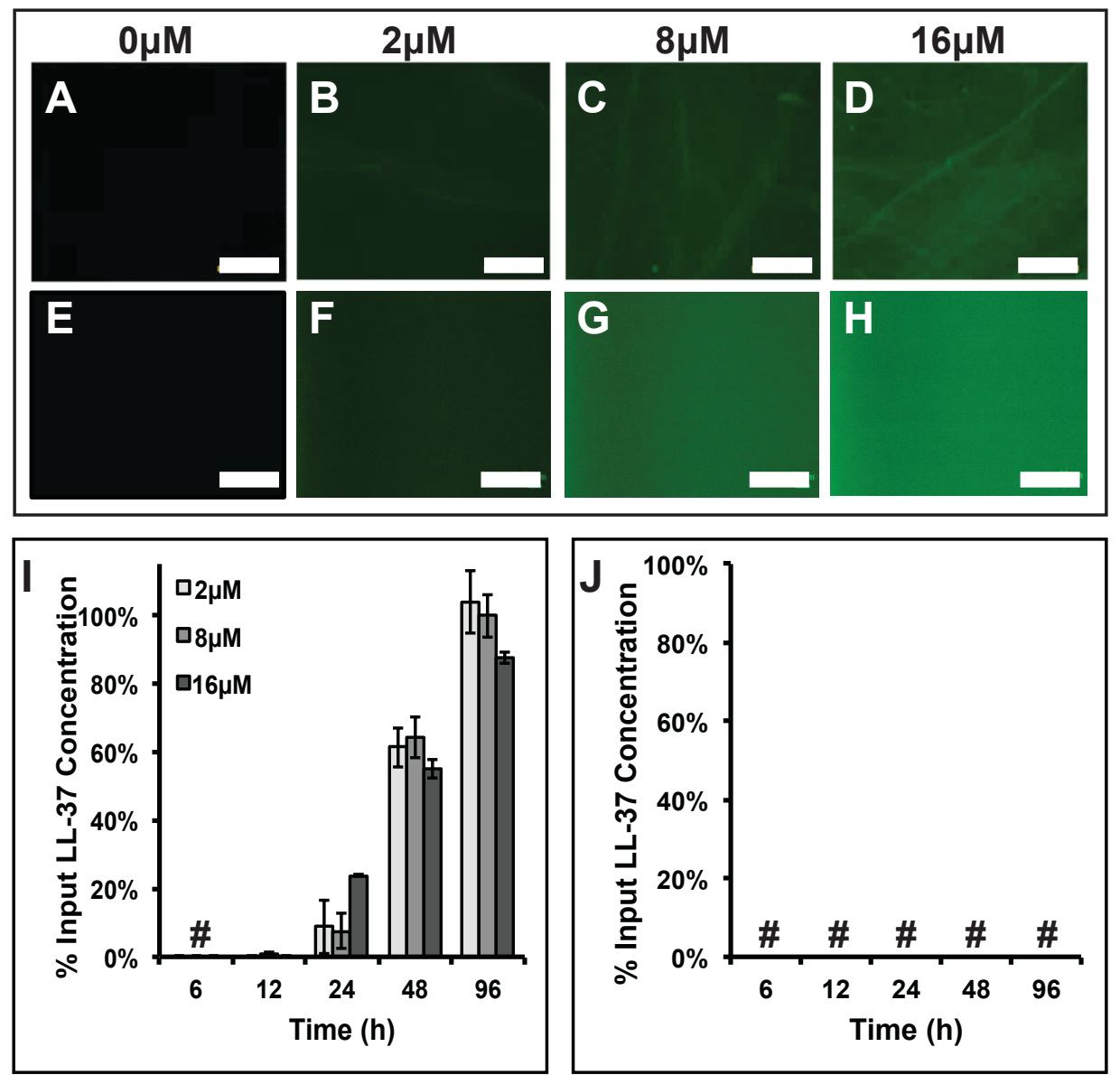

Figure 3 

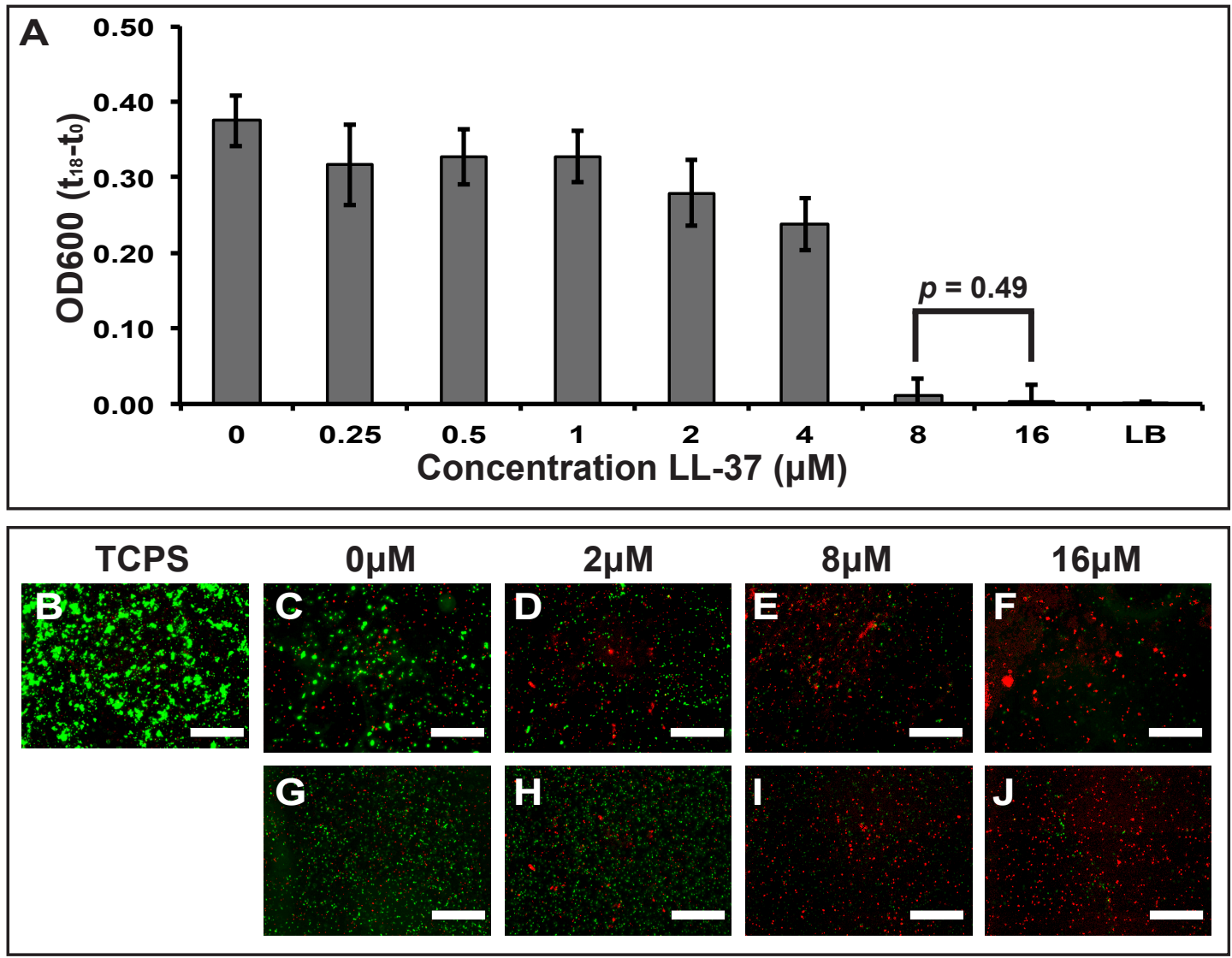

Figure 4 

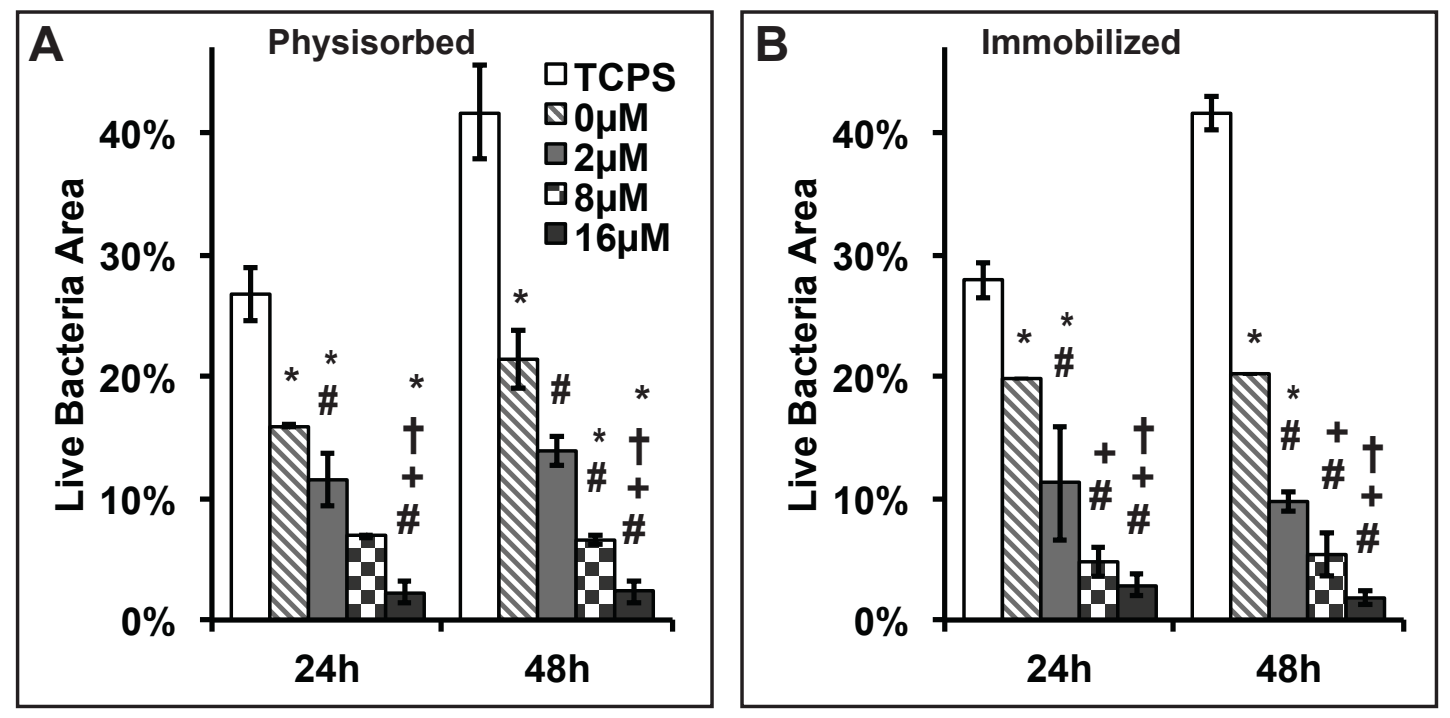

Figure 5 

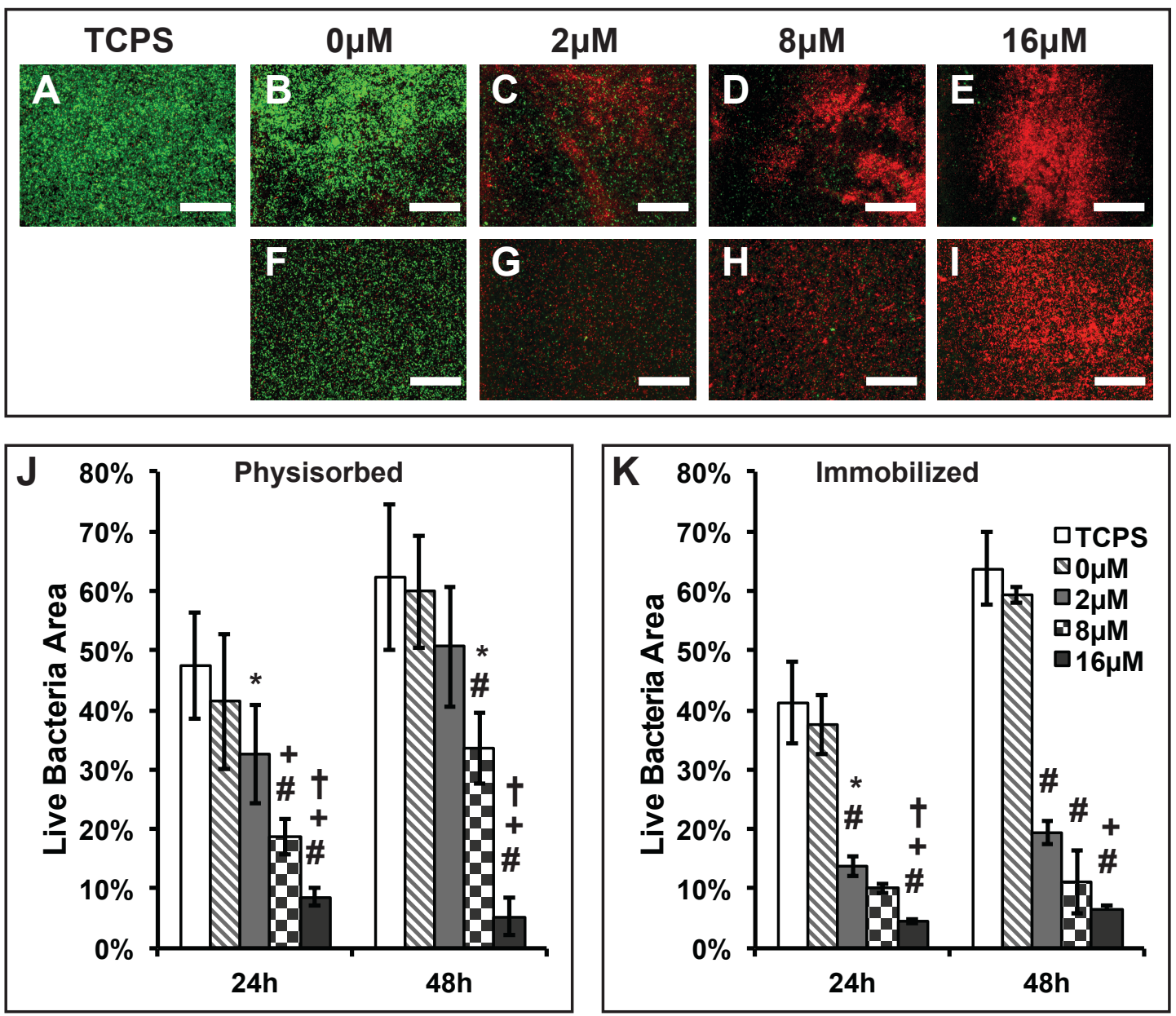

Figure 6 

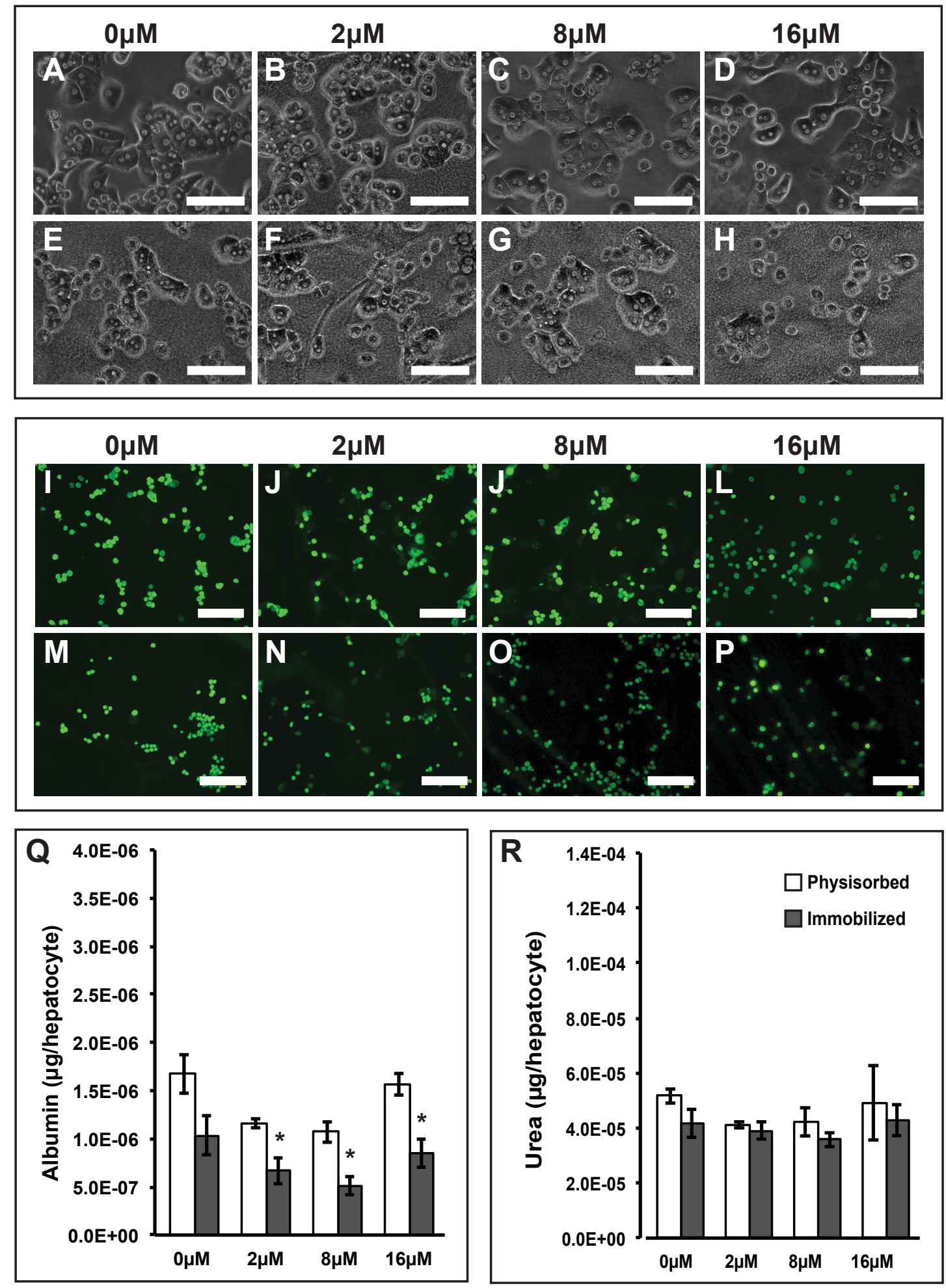

Figure 7 